\title{
Understanding Bank Valuation: An Application of the Equity Cash Flow and the Residual Income Approach in Bank Financial Accounting Statements
}

\author{
Eleftherios Aggelopoulos \\ Financial Accounting, Department of Business Administration, University of Patras, Rio-Patras, Greece \\ Email: eaggelopoulos@upatras.gr
}

How to cite this paper: Aggelopoulos, E. (2017) Understanding Bank Valuation: An Application of the Equity Cash Flow and the Residual Income Approach in Bank Financial Accounting Statements. Open Journal of Accounting, 6, 1-10.

http://dx.doi.org/10.4236/ojacct.2017.61001

Received: October 11, 2016

Accepted: December 2, 2016

Published: December 5, 2016

Copyright $\odot 2017$ by author and Scientific Research Publishing Inc. This work is licensed under the Creative Commons Attribution International License (CC BY 4.0).

http://creativecommons.org/licenses/by/4.0/ (c) (i)

Open Access

\begin{abstract}
The aim of this paper is to present a framework to bank valuation based on two generally acceptable valuation models that are not specific to banks: the model of discounted Equity Cash Flow to Equity (ECF) and the model of discounted Residual Income (RI). As emphasized by Koller, Goedhart and Wessels (pp. 663, 2005) [1] in a bestselling book on the valuation of firms, the valuation process of a financial institution is characterized by fundamental difficulties because of the peculiarities that characterize the function of banking business and also the lack of information on critical bank financial data, such as the quality of the loan portfolio. This means that estimates based on assumptions must be created for these data and in this direction this paper provides an analytical guideline. For carrying out the valuation of a financial institution, specific templates of banking accounting statements (i.e. a Balance Sheet and a Profit and Loss statement) proposed by Dermine (2009) [2] are used. The paper shows that both ECF and RI produce equivalent equity bank values. Given the recent financial crisis that has elevated the concern of banking institutions' soundness, it is important to illustrate in practice the existing bank accepted valuation methodologies in order to form a clear framework for measuring the value of a bank and assess bank performance. The proposed framework can be applied by bank practitioners.
\end{abstract}

\section{Keywords}

Banks, Valuation, Accounting Statements, Cash Flow to Equity, Residual Income

\section{Introduction}

In building a cash flow model of a bank from the outside, the Equity Cash Flow (ECF) 
method rather the enterprise Discounted Cash Flow (DCF) method should be used. The reason is that for banks, the operating and financing decisions cannot be separated since interest income and expense (components of financing decisions) are important elements of the bank's operating income. Therefore, in the proposed framework for valuing banks, the study uses the ECF method. Additionally, the paper utilizes a Residual Income (RI) method in order to confirm the theoretical justification of Koller, Goedhart and Wessels (2005) [1] that both approaches lead to the same results.

Both valuation models are based on discounting either future cash flows (ECF) or the periodic residual income (RI). To estimate future values of these variables is a prerequisite to predict the account figures of the bank's financial statements. Thus, a full income statement and a balance sheet along with an abbreviated schedule of changes in shareholder's equity which then lead to the equity cash flow, are utilized. Also, information about the Risk Weighted Assets (RWA) and Basel Tier 1 capital (equity and other capital that provides the most cushion for depositors and creditors) are used in order to incorporate some estimates of capital adequacy into the analysis. It is worth noting that the purpose of the current study is not to provide a comprehensive provisioning procedure, but to illustrate the various steps in the estimation of a bank's value.

The methodological procedure the study follows is the below: initially, a full income statement and a balance sheet, along with an abbreviated schedule of changes in shareholder's equity, are created. Then, forecasted financial statements are formed, based on specific assumptions. Thereafter, the future cash flows attributable to shareholders along with the terminal value of the bank are calculated. In the same manner, the residual income, created each year for shareholders along with the terminal value of the bank, is estimated. Then, through the use of the Capital Asset Pricing Model (CAPM) for the derivation of cost of equity, the cash flows and the terminal value are discounted and subsequently the equity value for the bank is derived. Also, the residual income and the terminal value are discounted and the sum of these components derives the equity value for the bank.

The main contribution of this tutorial paper is that presents analytically through an example a framework to bank valuation using the ECF and RI model. In addition, the paper explains the concept behind ECF and RI model as the appropriate valuation tools in banking and verifies the equivalence of both models. Moreover, the paper highlights in the conclusion section some important shareholder value determinants.

The paper is structured as follows: Section 2 presents the procedure for the preparation of primary financial statements for valuing purposes along with the assumptions that study hypotheses. Section 3 derives the equity value through the use of the discounted ECF model. Section 4 explains the discounted RI model and the final section concludes the paper.

\section{Preparation of the Accounting Financial Statements for Valuing Purposes}

The below financial accounting statement templates (Table 1: Balance Sheet, Table 2: Profit and Loss Statement) are utilized for the valuation purposes of this paper. 
Table 1. Balance sheet template for bank valuation.

\begin{tabular}{cc}
\hline Assets & Liabilities \\
\hline Cash & \\
Balances with BoG & Due to Banks \\
Due from Banks & Deposits \\
Securities \& Investments & Bonds Issued \\
Loans (net) & Deferred Tax Liability \\
PPE & Other Liabilities \\
Accrued Income & Total Shareholders' Equity \\
Other Assets & \\
Total Assets & Total liabilities and Shareholder Equity \\
\hline
\end{tabular}

Table 2. Profit and loss statement template for bank valuation.

\begin{tabular}{lc}
\hline$(+)$ & Interest \& Similar Income \\
$(-)$ & Interest Expense \& Similar Charges \\
\hline$(+)$ & Net Interest Income \\
\hline$(-)$ & Fee \& Commission Income \\
\hline$(+)$ & Fee \& Commission Expense \\
\hline & Net Fee \& Commission Income \\
\hline$(+)$ & Other Operating Income \\
$(+)$ & Total Operating Income \\
$(-)$ & Depreciation \\
$(-)$ & Other General Administrative Expenses \\
& Operating Expenses \\
\hline$(-)$ & Provision for Impairment \\
\hline & Profit Before Tax \\
\hline
\end{tabular}

The projection of the accounting data included in the financial statements, which form the future annual cash flow and the residual income, is a critical task in a bank valuation process (Gross, 2006) [3]. This is because the bank performance is affected by macroeconomic factors such as interest rate changes, capital markets volatility etc. (Brealey and Myers, 2000) [4]. This means that apart from the key financial figures, the evolution of these factors should be estimated, thus making even more difficult the quality of the projection. On the other hand, some qualitative characteristics that banks may present such as the existence of long term customer relationships makes easier the projection of bank's financial figures, an element which is not applicable in industrial enterprises (Gross, 2006) [3]. Generally, difficulties in projecting accounting data are presented in the valuation of any business. But especially in the case of banks, the process is more complicated, because banks are affected by macroeconomic factors.

The total forecasted period is divided into two phases: In the first phase the accounting data included on the financial statements are estimated, while in the second phase the terminal value of the bank is calculated. The first phase typically covers a five to ten-year period for industrial companies (Rappaport, 1986 [5]; Copeland, Koller and 
Murrin, 2000 [6]). In the case of banks, the average period is five years (Damodaran, 2009 [7]; MSDW, 2001 [8]; Dermine, 2009 [2]), while there are studies in the literature that utilize a ten-year period (Rezaee, 2001 [9]; Koller, Goedhart and Wessels, 2005 [1]). Generally, the duration of the observing period must be such in order to incorporate a business cycle and also structural change effects. In this paper the analytical period is eight years and then the terminal value of the bank is estimated.

As it is explained in the introduction, the priority is not to focus on the provision of balance sheet accounts. The literature mentions both qualitative and quantitative methods for predicting future financial performance of banks. Usually, the quantitative methods (due to available data) are used through a time series analysis, where the future performance based on historical accounting data is formed (Damodaran, 2009 [7]). In our case, the projections of the accounts of the financial statements are based on assumptions that are explained analytically below.

Tables 3-8 present in detail the employed accounting statements for valuing purposes covering the analytical eight-year period: The Balance Sheet, the calculation of RWA and the required regulatory capital, the statement of change of the bank's equity, the Profit and Loss statement, the calculation of ECF and RI respectively.

As regards the balance sheet (Table 3) and in particular its assets side, it is assumed

Table 3. Bank balance sheet for valuation purposes (historical and future data).

\begin{tabular}{|c|c|c|c|c|c|c|c|c|c|c|}
\hline Assets & $\underline{0 \text { (today) }}$ & $\underline{1^{\circ} \text { year }}$ & $\underline{2^{\circ} \text { year }}$ & $3^{\circ}$ year & $\underline{4^{\circ} \text { year }}$ & $\underline{5^{\circ} \text { year }}$ & $6^{\circ}$ year & $\underline{7^{\circ} \text { year }}$ & $\underline{8^{\circ} \text { year }}$ & $\underline{9^{\circ} \text { year }}$ \\
\hline Cash & 100 & 100 & 100 & 100 & 100 & 100 & 100 & 100 & 100 & 100 \\
\hline Balances with Central Bank & 63 & 65 & 67 & 69 & 71 & 73 & 75 & 77 & 80 & 82 \\
\hline Due from Banks & 350 & 360 & 370 & 380 & 390 & 400 & 410 & 420 & 430 & 450 \\
\hline Securities and Investments & 350 & 360 & 370 & 380 & 390 & 400 & 410 & 420 & 430 & 450 \\
\hline Loans (net) & 3500 & 3605 & 3713 & 3825 & 3939 & 4057 & 4179 & 4305 & 4434 & 4567 \\
\hline Fixed Tangible Assets & 175 & 180 & 186 & 191 & 197 & 203 & 209 & 215 & 222 & 228 \\
\hline TOTAL Assets & 4538 & 4670 & 4806 & 4945 & 5087 & 5233 & 5383 & 5537 & 5695 & 5877 \\
\hline \multicolumn{11}{|l|}{ LIABILITIES } \\
\hline Due to Banks & 1059 & 1094 & 1122 & 1151 & 1180 & 1209 & 1239 & 1268 & 1299 & 1348 \\
\hline Customer Deposits & 3150 & 3245 & 3342 & 3442 & 3545 & 3652 & 3761 & 3874 & 3990 & 4110 \\
\hline Bonds Issued & - & - & - & - & - & - & - & - & - & - \\
\hline Other Liabilities & - & - & - & - & - & - & - & - & - & - \\
\hline Total Shareholder Equity & 329 & 332 & 341 & 352 & 362 & 373 & 384 & 395 & 406 & 419 \\
\hline Total Liabilities and Equity & 4538 & 4670 & 4806 & 4945 & 5087 & 5233 & 5383 & 5537 & 5695 & 5877 \\
\hline
\end{tabular}

Table 4. Calculation of the risk weighted assets and total regulatory required capital (future data).

\begin{tabular}{|c|c|c|c|c|c|c|c|c|c|}
\hline & $\underline{1^{\circ} \text { year }}$ & $\underline{2^{\circ} \text { year }}$ & $\underline{3^{\circ} \text { year }}$ & $\underline{4^{\circ} \text { year }}$ & $\underline{5^{\circ} \text { year }}$ & $6^{\circ}$ year & $\underline{7^{\circ} \text { year }}$ & $\underline{8^{\circ} \text { year }}$ & $\underline{9^{\circ} \text { year }}$ \\
\hline Risk Weighted Assets (RWA)* & 3316 & 3415 & 3516 & 3619 & 3726 & 3835 & 3948 & 4063 & 4193 \\
\hline $\begin{array}{l}\text { Tier } 1(8 \%) \text { for the Minimum Required Capital and } \\
\text { Additional Capital (2\%) for Growth Purposes }\end{array}$ & $10 \%$ & $10 \%$ & $10 \%$ & $10 \%$ & $10 \%$ & $10 \%$ & $10 \%$ & $10 \%$ & $10 \%$ \\
\hline Total Regulatory Capital & 332 & 341 & 352 & 362 & 373 & 384 & 395 & 406 & 419 \\
\hline
\end{tabular}

${ }^{\star}$ Due for banks are weighted with $20 \%$, loans with $75 \%$, securities and investments and tangible assets with $100 \%$ and cash-balances with Central Banks with $0 \%$. 
Table 5. Equity movement (future data).

\begin{tabular}{|c|c|c|c|c|c|c|c|c|c|}
\hline Years & $1^{\circ}$ year & $2^{\circ}$ year & $3^{\circ}$ year & $\underline{4^{\circ} \text { year }}$ & $\underline{5^{\circ} \text { year }}$ & $6^{\circ}$ year & $7^{\circ}$ year & $8^{\circ}$ year & $9^{\circ}$ year \\
\hline Equity (Beginning of the Year) & 329 & 332 & 341 & 352 & 362 & 373 & 384 & 395 & 406 \\
\hline (+) Share Capital Increase & - & - & - & - & - & - & - & - & - \\
\hline (+) Profit for the Period (from Table 4) & 112 & 115 & 119 & 122 & 126 & 130 & 134 & 138 & 142 \\
\hline (-) Dividends and Potential Dividends & 109 & 106 & 109 & 112 & 115 & 119 & 122 & 126 & 129 \\
\hline Equity (End of Year) (as It Is Derived from the Above Table) & 332 & 341 & 352 & 362 & 373 & 384 & 395 & 406 & 419 \\
\hline
\end{tabular}

Table 6. Bank's profit and loss statement for banking purposes (historical and future data).

\begin{tabular}{|c|c|c|c|c|c|c|c|c|c|c|}
\hline & $\underline{0 \text { (present) }}$ & $\underline{1^{\circ} \text { year }}$ & $\underline{2^{\circ} \text { year }}$ & $3^{\circ}$ year & $\underline{4^{\circ} \text { year }}$ & $\underline{5^{\circ} \text { year }}$ & $6^{\circ}$ year & $\underline{7^{\circ} \text { year }}$ & $\underline{8^{\circ} \text { year }}$ & $\underline{9^{\circ} \text { year }}$ \\
\hline Interest and Similar Income & 77 & 79 & 82 & 84 & 87 & 89 & 92 & 94 & 97 & 101 \\
\hline$(+)$ Fee and Commissions Income & 15 & 16 & 16 & 17 & 17 & 18 & 18 & 19 & 19 & 20 \\
\hline$(+)$ Other Operating Income & 8 & 8 & 8 & 8 & 9 & 9 & 9 & 9 & 10 & 10 \\
\hline Total Operating Income & 100 & 103 & 106 & 109 & 113 & 116 & 119 & 123 & 126 & 130 \\
\hline (-) Depreciation & 9 & 9 & 9 & 10 & 10 & 10 & 10 & 11 & 11 & 11 \\
\hline (-) Other General Administrative Expenses & 61 & 63 & 65 & 67 & 69 & 71 & 73 & 75 & 77 & 80 \\
\hline (-) Provision for Impairment & 25 & 26 & 27 & 27 & 28 & 29 & 30 & 31 & 32 & 33 \\
\hline Profit before Tax & 145 & 149 & 154 & 159 & 163 & 168 & 173 & 178 & 183 & 189 \\
\hline (-) Income Tax & 36 & 37 & 38 & 40 & 41 & 42 & 43 & 45 & 46 & 47 \\
\hline Net Profit & 109 & 112 & 115 & 119 & 122 & 126 & 130 & 134 & 138 & 142 \\
\hline
\end{tabular}

that the customer loan balances increase at an annual growth rate of 3\% (its increase is in line with the annual growth rate of nominal GDP). Loans to other credit institutions and the value of securities and investments are predicted to increase by 10 units per year, while for the year after the analytical eight years' period, by 20 points. Deposit balances at the central bank are calculated as a proportion of $2 \%$ of the annual amounts of the total deposits (following the ECB guidelines) while the bank's own cash balance is considered fixed over time. Also, the value of property is assumed to correspond every year to $5 \%$ of the loan balances.

Regarding liabilities, it is considered that the bank maintains throughout the analytical period a fixed ratio of loans to deposits equal to $90 \%$. For the calculation of the annual equity the minimum bank capital required defined by Basel rules (the Basel I ratio) is used, which corresponds to at least $8 \%$ of the RWA. At the regulatory rate of $8 \%$, two percentage points are added. This is justified by the fact that the bank must have additional funds (beyond the minimum requirement for capital) in order to exploit possible future investment opportunities. So, for each year the RWA are calculated (Table 4) according to specific weights that are applied to each asset category (i.e. these weights are defined by the central bank).

In the paper's example, the weights below are applied: $75 \%$ for customer loan balances, $20 \%$ for loans to financial institutions, $0 \%$ for cash equivalents and $100 \%$ for all other assets. Then, the sum of RWA for each year is multiplied by $10 \%$ and thus the capital required by the bank at the end of each year is derived. Then (Table 5) a check 
Table 7. Calculation of Free Cash Flow to Equity (FCFE, 2 methods, future data).

\begin{tabular}{|c|c|c|c|c|c|c|c|c|c|}
\hline & $\underline{1^{\circ} \text { year }}$ & $\underline{2^{\circ} \text { year }}$ & $\underline{3^{\circ} \text { year }}$ & $\underline{4^{\circ} \text { year }}$ & $\underline{5^{\circ} \text { year }}$ & $6^{\circ}$ year & $\underline{7^{\circ} \text { year }}$ & $8^{\circ}$ year & $\underline{9^{\circ} \text { year }}$ \\
\hline Net Income & 112 & 115 & 119 & 122 & 126 & 130 & 134 & 138 & 142 \\
\hline (+) Depreciation & 9 & 9 & 10 & 10 & 10 & 10 & 11 & 11 & 11 \\
\hline$(-)$ Net Increase in Loans & 105 & 108 & 111 & 115 & 118 & 122 & 125 & 129 & 133 \\
\hline$(-)$ Net Increase in Securities and Investments & 10 & 10 & 10 & 10 & 10 & 10 & 10 & 10 & 20 \\
\hline$(-)$ Net Increase in Amounts due from Banks & 12 & 12 & 12 & 12 & 12 & 12 & 12 & 12 & 22 \\
\hline (-) Net Capital Expenditure & 14 & 15 & 15 & 16 & 16 & 17 & 17 & 18 & 18 \\
\hline$(+)$ Net Increase in Deposits & 95 & 97 & 100 & 103 & 106 & 110 & 113 & 116 & 120 \\
\hline (+) Net Increase in Interbank Funds & 35 & 28 & 29 & 29 & 29 & 30 & 30 & 30 & 49 \\
\hline Equity Cash Flow & 109 & 106 & 109 & 112 & 115 & 119 & 122 & 126 & 129 \\
\hline \multicolumn{10}{|c|}{ Robustness check for the calculation of FCFE (second method, Koller Goedhart and Wessels, 2005 [1]) } \\
\hline (+) Dividends and Potential divIdends & 109 & 106 & 109 & 112 & 115 & 119 & 122 & 126 & 129 \\
\hline (-) Share Capital Issue (Repurchase) & - & - & - & - & - & - & - & - & - \\
\hline Equity Cash Flow (ECF) & 109 & 106 & 109 & 112 & 115 & 119 & 122 & 126 & 129 \\
\hline
\end{tabular}

Present Value of ECF

$99^{*}(0.909)^{* *} 87(0.826) 82(0.751) 77(0.683) 72(0.621) 67(0.565) 63(0.513) 59(0.466)$

Terminal Value

$1420^{* * *}$

Present value of Terminal Value

EQUITY VALUE: Present Value of ECF + Present Value of terminal value $=605+662=1267$

${ }^{*}$ The PV of ECF with a discounting rate of $10 \%$ according to CAPM. ${ }^{* *}$ Is the PV of 1 monetary unit. ${ }^{* *}$ The terminal value of the bank is derived if we divide the net profit of year $9(142)$ to the cost of equity $(10 \%)$. ${ }^{* * *}$ Is the PV of terminal value with a discounting rate of $10 \%$.

Table 8. Calculation of RI (RI, future data).

\begin{tabular}{|c|c|c|c|c|c|c|c|c|c|}
\hline & $1^{\circ}$ year & $2^{\circ}$ year & $3^{\circ}$ year & $4^{\circ}$ year & $5^{\circ}$ year & $6^{\circ}$ year & $\underline{7^{\circ} \text { year }}$ & $8^{\circ}$ year & $9^{\circ}$ year \\
\hline Net Income & 112 & 115 & 119 & 122 & 126 & 130 & 134 & 138 & 142 \\
\hline $\begin{array}{l}\text { (-) Cost of the Capital Employed } \\
\text { (Equity b.o.y. }{ }^{*} \text { Cost of Equity } 10 \% \text { ) }\end{array}$ & 33 & 33 & 34 & 35 & 36 & 38 & 39 & 40 & 41 \\
\hline Residual Income & 79 & 82 & 85 & 87 & 90 & 92 & 95 & 98 & 101 \\
\hline Present Value of Residual Income & $72^{\star}(0.909)^{\star *}$ & $68(0.826)$ & $64(0.751)$ & $60(0.683)$ & $56(0.621)$ & $52(0.565)$ & $49(0.513)$ & $46(0.466)$ & - \\
\hline Terminal Value & - & - & - & - & - & - & - & - & $1010^{* * *}$ \\
\hline Present Value of Terminal Value & - & - & - & - & - & - & - & - & $471^{\star * * *}(0.4241)^{\star *}$ \\
\hline
\end{tabular}

${ }^{\star}$ Is the PV of Residual Income with a discounting rate of $10 \%$ according to CAPM. ${ }^{* *}$ Is the PV of 1 monetary unit. ${ }^{* *}$ The terminal value of the bank is derived if we divide residual income of year 9 (101) to the cost of equity (10\%). ${ }^{* * * *}$ Is the PV of terminal value with a discounting rate of $10 \%$.

takes place, if the required capital each year is covered by the annual profits and if an excess amount arises that is distributed to shareholders as dividend. Otherwise, an equity increase should take place in order to ensure the required capital level. Finally, liabilities to credit institutions each year are derived from the difference between total equity and total assets (i.e. an assumption is made that the capital structure does not vary over time).

For the income statement (Table 6) the assumptions below are made. A net profit margin of $2 \%$ (stable throughout the analytical period) is estimated which is applied on the loan balances and thus the annual net interest income is calculated. The net com- 
mission income is associated with the net interest income with an assumption that they represent $20 \%$ of them, while the other operating income corresponds each year to $10 \%$ of the net interest income. Also, operating expenses are calculated as the $70 \%$ of total operating revenues, while the projected impairment loan losses are assumed to be the $25 \%$ of net interest income on loans. Finally, the net annual profit is derived if from the pre-tax profit, an income tax based on a tax rate of $25 \%$ is subtracted.

\section{The Equity Cash Flow Valuation Model}

According to the previous section, one of the most appropriate models for valuing financial institutions is that of discounted ECF. The bank's equity cash flows can be calculated either directly (direct approach) or indirectly (indirect approach), where both approaches lead to the same result. According to Gross (p. 49, 2006 [3]), banks in practice calculate equity cash flows with the indirect method. This is due to the difficulty in allocating cash flows to operating, financial and investment activity. Also, Koller, Goedhart and Wessels, (2005) [1] suggest as an alternative method of calculating cash flows, the sum of cash received or paid by shareholders, including dividends, share repurchases and share capital increases. In our example, the cash flows will be calculated with the indirect method.

The methodological steps for the derivation of the bank's equity value are described below: First, the cash flows with the indirect method are calculated (Table 7). The starting point is the accounting net profit after tax (which is derived from the income statement), which is the gain that theoretically is available to bank shareholders, after having previously covered all costs namely accounting and financial charges. However, the accounting profit is not a net cash flow since for its determination, accounting expenses that are not cash flow have been taken into account (for example the accounting expense of the depreciation, which is added in our calculations). To derive at the EQF value, the net investments in working capital and fixed assets are subtracted (changes in assets between the two periods) and the net inflow related to debt capital is added (considered cash inflows). In particular, the positive movements in the balance of customer loans, loans to financial institutions, securities and investment and fixed assets are subtracted. At the same time, the changes in deposit balances and liabilities to other credit institutions are added, thus deriving to the cash flows attributable to shareholders each year (i.e. the ECF). The same amount of ECF is derived if the calculation method proposed by Koller, Goedhart and Wessels, (2005) [1] is applied. In particular, bank shareholders each year earn dividends from the total bank profit (Table 7). Conversely, the participation of shareholders in a bank's capital increase is considered as a cash outflow. With the above two methods, the ECF per year for the analytical period is calculated.

The second step is to determine the terminal value of the bank, for the period after the analytical calculations. For its calculation, the formula proposed by Copeland, Koller and Murrin (2000) [6] is used, where the net profit after taxes (i.e. the first year after the end of the analytical period) is divided to the cost of equity of the bank. To calculate the cost of equity, which corresponds to the minimum return required by shareholders on their investment in the bank, the Capital Asset Pricing Model (CAPM) is utilized. 
CAPM is widely used in the valuation of banks (Koller, Goedhart and Wessels, 2005 [1]; Dermine 2009 [2]; MSDW, 2001 [8]; Fiordelisi and Molyneux, 2010 [10]; Gross, 2006 [3]). The formula is as follows:

$$
c_{e t}=r_{f t}+\left[E\left(r_{m}\right)-r_{f t}\right] x b e t a
$$

where:

$$
\begin{aligned}
& c_{e t}=\text { Cost of equity } \\
& r_{f t}=\text { Risk-free rate of return } \\
& E\left(r_{m}\right)=\text { Expected rate of return on the market portfolio } \\
& E\left(r_{m}\right)-r_{f t}=\text { Market risk premium constant over time } \\
& \text { beta }=\text { Systematic risk of the bank. }
\end{aligned}
$$

The cost of equity is equal to the yield of a risk-free debt instrument plus the systematic risk of the bank, where the latter previously has been multiplied by the market risk premium. In banking literature, the yield on ten-year government bonds is used as an indicator of risk free rate (Copeland, Koller and Murrin, 2000 [6]; Koller, Goedhart and Wessels, 2005 [1]; Gross, 2006 [3]; Fiordelisi and Molyneux, 2010 [10]). The systematic risk of the bank (beta coefficient) indicates the degree of correlation of bank performance and market portfolio where a value of 1 indicates a high correlation with the market and otherwise 0 no correlation. The beta factor is calculated using historical data of correlation between market returns and bank returns. The literature (MSDW, 2001 [8]; Copeland, Koller and Murrin, 2000 [6]) suggests the use of published estimates of beta coefficients from the available databases (Data Stream, Bloomberg, etc.). On contrary, the Brealey and Myers (2000) [4] support the use of an average beta of individual banks in the sector, assuming that each bank in the industry faces the same operational risks, therefore should have a similar beta. Also, computational errors of individual beta tend to offset each other in the calculation of the average beta of bank sector, with a result the latter to be considered more reliable than the beta of an individual bank (Annema and Goedhart, 2003) [11]. The market risk premium is the difference between the expected return on the market portfolio and the yield of a ten-year government bond. Empirical investigations based on historical performance of the market and government bonds showed that investments in equities outperform from $4 \%$ to $6 \%$ the yields of low risk securities (Ogier, Rugman and Spicer, 2004) [12]. Especially for the bank valuation, a risk premium of about $5 \%$ is utilized based on historical empirical research (Dermine and Bissada, 2007) [13].

The final step, after the calculation of the analytical cash flows and the terminal value of the bank, is to discount these cash flows and the terminal value in present values using as a discount rate the cost of equity, as shown above through the usage of CAPM (assume 10\% in our example). The sum of the present value of cash flows and terminal value of the bank, gives the ECF value (Table 7).

\section{The Residual Income Valuation Method}

In order to verify the derived bank equity (ECF model), an alternative bank valuation model is utilized based on discounted residual income (Table 8). As mentioned above, the two methods theoretically should lead to the same result when properly applied 
(Koller, Goedhart and Wessels, 2005) [1].

The methodological steps for the derivation of the bank's equity value are described below: First, the residual income (RI) for the analytical period of eight years is calculated. RI is the difference between operating profits after taxes and the cost of equity capital employed. The latter equals the previous year's total equity multiplied by the cost of equity according to CAPM. Second, the terminal value of the bank in perpetuity is estimated by dividing the residual income of the year following the analytical period with the cost of equity (Gross, 2006) [3]. Third, the derived residual incomes are discounted and the present value of RI is obtained. The final step is to sum the present value of residual income (analytical period and in perpetuity) with the value of bank equity at the beginning of the study period, thus deriving the current value of the equity of the bank.

\section{Conclusions}

The purpose of this tutorial paper is to propose an analytical guideline to bank valuation. The occurrence of recent banking crisis with contagion effects to the real economy has demonstrated the importance of valuing and assessing correctly the bank performance and in this direction this paper attempts to illustrate in practice the existing bank accepted valuation. The paper employs two valuation methods appropriate for valuing financial institutions based on discounted equity cash flows and residual incomes respectively.

The study finds that both models lead to the same equity value (1267 monetary units) thus verifying the theoretical justification of Koller, Goedhart and Wessels, (2005) [1] for the equivalence of both models. Also, the derived equity value is about four times greater than the current value of the equity of the bank (the current value of the equity is 329 units). Moreover, the analytical illustration of the derivation of the ECF and RI reveals that the main shareholder value determinant is the bank's ability to grow and invest its employed shareholder's capital with a return that exceeds the minimum rate of return that shareholders require. Thus, high yields on invested capital and development of banking operations lead to high cash flows and annual residual incomes thus enhancing the bank's value.

\section{Acknowledgements}

In memory of Professor Vasilios Spiropoulos, Department of Accounting, Technological Institute of Patras, Greece.

\section{References}

[1] Koller, T., Goedhart, M. and Wessels, D. (2005) Measuring and Managing the Value of Companies. 4th Edition, Mc Kinsey \& Company, New Jersey.

[2] Dermine, J. (2009) Bank Valuation and Value-Based Management. McGraw-Hill, New York.

[3] Gross, S. (2006) Banks and Shareholder Value. An Overview of Bank Valuation and Empirical Evidence on Shareholder Value for Banks. DUV Gabler Edition Wissenschaft, Frankfurt.

[4] Brealey, R. and Myers, S. (2000) Principles of Corporate Finance. 6th Edition, McGraw- 
Hill/Irwin, Boston.

[5] Rappaport, A. (1986) Creating Shareholder Value: The New Standard for Business Performance. Simer and Schuster Publishing Group, New York.

[6] Copeland, T., Koller, T. and Murrin, J, (2000) Valuation: Measuring and Managing the Value of Companies. 3rd Edition, McKinsey \& Company, New York.

[7] Damodaran, A. (2009) Valuing Financial Service Firms. Stern Business School, New York University, New York. http://people.stern.nyu.edu/adamodar/pdfiles/papers/finfirm09.pdf

[8] Morgan Stanley Dean Witter \& Co (MSDW) (2001) Valuing Financial Stocks with Residual Income, Morgan Stanley Dean Witter, Equity Research North America.

[9] Rezaee, Z. (2001) Financial Institutions, Valuations, Mergers and Acquisitions: The Fair Value Approach. 2nd Edition, Wiley, New York.

[10] Fiordelisi, F. and Molyneux, P. (2010) The Determinants of Shareholder Value in European Banking. Journal of Banking and Finance, 35, 1189-1200. https://doi.org/10.1016/j.jbankfin.2009.11.018

[11] Annema, A. and Goedhart, M. (2003) Better Betas. Mc Kinsey on Finance, 6, 10-13.

[12] Ogier, T., Rugman, J. and Spicer, L. (2004) The Real Cost of Capital. FT Prentice Hall, London.

[13] Dermine, J. and Bissada, J. (2007) Asset and Liability Management, a Banker's Guide to Value Creation and Risk Control. 2nd Edition, FT Prentice Hall, London.

\section{Submit or recommend next manuscript to SCIRP and we will provide best service for you:}

Accepting pre-submission inquiries through Email, Facebook, LinkedIn, Twitter, etc.

A wide selection of journals (inclusive of 9 subjects, more than 200 journals)

Providing 24-hour high-quality service

User-friendly online submission system

Fair and swift peer-review system

Efficient typesetting and proofreading procedure

Display of the result of downloads and visits, as well as the number of cited articles

Maximum dissemination of your research work

Submit your manuscript at: http://papersubmission.scirp.org/

Or contact ojacct@scirp.org 